九州大学学術情報リポジトリ

Kyushu University Institutional Repository

\title{
Effect of Salt Concentrations on the Permeability and Compressibility of Soil- Bentonite Mixtures
}

Mishra, Anil Kumar

Graduate School of Bioresource and Bioenvironmental Sciences, Kyushu Unviersity

Ohtsubo, Masami

Department of Bioresource and Environmental Science, Kyushu University

Li, Loretta

The University of British Columbia, Vancouver, B. C. Canada

Higashi, Takahiro

Graduate School of Bioresource and Bioenvironmental Sciences, Kyushu Unviersity

https://doi.org/10.5109/4692

出版情報：九州大学大学院農学研究院紀要. 50 (2)，pp. 837-849，2005-10-01. Faculty of Agriculture, Kyushu University

バージョン :

権利関係 : 


\title{
Effect of Salt Concentrations on the Permeability and Compressibility of Soil-Bentonite Mixtures
}

\section{Anil Kumar MISHRA ${ }^{1 *}$, Masami OHTSUBO ${ }^{2}$, Loretta LI $^{3}$ and Takahiro HIGASHI ${ }^{2}$}

\author{
Laboratory of Soil Environmental Engineering, Division of Regional Environmental Science, \\ Department of Bioresource and Environmental Science, Faculty of Agriculture, \\ Kyushu University, Fukuoka-812-8581, Japan \\ (Received June 30, 2005 and accepted July 26, 2005)
}

\begin{abstract}
The influence of $\mathrm{NaCl}$ and $\mathrm{CaCl}_{2}$ at various concentrations on permeability and compressibility of mixtures of basalt soil and bentonite has been investigated. Comparison of hydraulic conductivity $(k)$ for different salt solutions shows that the divalent cation have more effect than monovalent cation. Comparison of different salt concentrations for a particular salt on a particular soil mixture shows that the $k$ decreases with decreasing salt concentration. This decrease can be attributed to an increase in diffuse double layer thickness. A change in salt concentration from 0 (Deionized Water) to $0.01 \mathrm{~mol}_{c} / \mathrm{L}$ did not produce any significant effect on the $k$ for the basalt soil-bentonite mixture of proportion 100:20, but a further increase in salt concentration had a pronounced effect on $k$. The compressibility of the soil mixtures was reduced with increasing salt concentration of the pore fluid.
\end{abstract}

Key words: Clay, permeability, compressibility, salt solution, liquid limit, swelling, diffuse double layer thickness

\section{INTRODUCTION}

Clay liners are frequently installed at waste disposal sites to prevent pollutant migration and to minimize or eliminate the risk for ground water contamination due to low permeability and adsorption capability of the liner material. Liner materials generally consist of mixtures of the bentonite and a locally available soil. The presence of bentonite, which is primarily composed of mineral montmorillonite reduces the hydraulic conductivity of the liner material. Fine particles, interlayer swelling and a thick layer of bound water associated with montmorillonite cause bentonite to exhibit low permeability to passage of water (Mesri and Olson 1971). These factors however make the bentonite sensitive to chemical interactions which can cause the hydraulic conductivity to increase (Gleason et al., 1997; Petrov et al., 1997; Ruhl and Daniel 1997). Chemicals in the landfill leachate with low dielectric constant, high electrolyte concentration, or high cation valence may cause the diffuse double layer of bentonite to shrink which in turn leads to

1 Laboratory of Soil Environmental Engineering, Division of Regional Environmental Science, Department of Bioresource and Environmental Science, Graduate school of Bioproduction and Environmental Sciences, Kyushu University

${ }^{2}$ Laboratory of Soil Environmental Engineering, Division of Regional Environmental Science, Department of Bioresource and Environmental Science, Kyushu University

${ }^{3}$ Department of Civil Engineering, The University of British Columbia, Vancouver, B. C, Canada

* Corresponding author (E-mail: anilk_iisc@yahoo.co.in) 
an increase in the hydraulic conductivity. This would also cause the change in the compressibility of liner materials under overburden pressures.

With the growing economy of Japan, the generation of municipal solid waste has reached 50 million tonnes per year. Due to limited availability of land, this huge amount of waste has been reduced by incineration with the residue of fly ash and bottom ash disposed in controlled landfills having a chemical compatible clay liner of hydraulic conductivity $<1 \times 10^{-6} \mathrm{~cm} / \mathrm{sec}$. For engineered landfill sites, the performance of clay liners is based on retention capacity and low hydraulic conductivity, which could be effected by the presence of cations like $\mathrm{Na}$ and $\mathrm{Ca}$ in the fly ash and bottom ash (Ohtsubo et al., 2004). Presence of these salts could affect the hydraulic conductivity of soil liner and reduce the sorption capacity of heavy metals onto the soil liner (Yong and Sheremata 1991), in turn reducing the usefulness of the liner. In order to design a secure clay liner, it is important to have a better understanding of the effect of those cations of different concentration on the liner material.

Numerous studies have been made on the effect of these salt solutions on the permeability of the bentonite alone (Olson and Mesri 1970; Mesri and Olson 1971; Petrov et al., 1997; Jo et al., 2001). Very few attempts (Studds et al., 1998) have been made to study the effect of salt solutions on the permeability of the soil mixtures, though in a real situation a mixture of locally available soil and bentonite constitute the clay liner material. In regards to the determination of the hydraulic conductivity of clayey soil, the consolidation test has been widely used (Newland and Alley 1960, Mesri and Olson 1971, Budhu et al., 1991, Sivapullaiah et al., 2000). This test generally provides the hydraulic conductivity comparable with the permeability test (Terzaghi 1923, Casagrande and Fadum 1944) although slightly underestimates the hydraulic conductivity compared with the permeability test (Taylor 1942, Mitchell and Madson 1987). The purpose of this study was to investigate the change in the properties such as hydraulic conductivity and compressibility of basalt soil and bentonite mixtures due to permeation of $\mathrm{NaCl}$ and $\mathrm{CaCl}_{2}$ of various concentrations using a consolidation test.

\section{MATERIALS AND METHODS}

\section{Materials}

For the liquid limit and consolidation tests, the mixtures of weathered basalt soil (referred as basalt soil hereafter) and bentonite in the dry weight proportion of 100:20 and 100:10 were used. The bentonite was used as a buffering material for the clay liner. The basalt soil was collected from Uwaba plateau of Saga prefecture, Japan. The samples for the test were prepared by adding solutions with various concentrations, namely $1,0.1$, $0.01,0.001$ and $0 \mathrm{~mol}_{c} / \mathrm{L}$ (i.e. deionized (DI) water). The symbol of $\mathrm{mol}_{\mathrm{c}} / \mathrm{L}$ indicates the unit of mole charge per liter, which is equivalent to the formerly used normality $(\mathrm{N})$.

The particle size distribution was obtained by dry sieving and hydrometer analysis as per ASTM D $422.70 .5 \%$ by weight of the particles of basalt soil were smaller than $75 \mu \mathrm{m}$ in diameter. The physical and chemical properties of the bentonite and basalt soil are presented in Table 1. 
Table 1. Properties of basalt soil and bentonite

\begin{tabular}{lcc}
\hline \multicolumn{1}{c}{ Properties } & Basalt & Bentonite \\
\hline Liquid limit (\%) & 57.1 & 310.5 \\
Plastic limit (\%) & 29.1 & 54.1 \\
Specific gravity & 2.93 & 2.54 \\
Clay $(<2 \mu \mathrm{m})$ content $(\%)$ & 10.1 & 61.4 \\
Cation Exchange Capacity $\left(\mathrm{cmol}_{\mathrm{c}} / \mathrm{kg}\right)$ & 20.0 & 52.8 \\
\hline
\end{tabular}

\section{Free swell test}

The free swell test on the bentonite was conducted according to ASTM D 5890 using DI water and $0.01,0.1$ and $1 \mathrm{~mol}_{\mathrm{c}} / \mathrm{L} \mathrm{NaCl}$ and $\mathrm{CaCl}_{2}$ solutions. Approximately $90 \mathrm{~mL}$ of DI water or salt solution was poured into a $100 \mathrm{~mL}$ graduated cylinder and two grams of dry powdered bentonite was placed in the salt solution in $0.1 \mathrm{~g}$ increments. Then the cylinder was rinsed with salt solution or DI water and was filled up to the $100 \mathrm{~mL}$. After $24 \mathrm{~h}$ of exposure the swollen volume of the bentonite was measured.

\section{Physical properties of mixtures}

The compaction curves (i.e. water content vs dry density relationship) for the two mixtures were determined by adding DI water in accordance with the standard proctor test described in ASTM standard D 698. The liquid limit of the mixtures was determined by both the Casagrande's method (ASTM D 4318) and falling cone method by adding salt solutions with different concentration to dried soil mixtures.

\section{Consolidation test}

Consolidation tests were carried out to determine the hydraulic conductivity and compressibility of the samples. The tests were carried out on the sample of $60 \mathrm{~mm}$ diameter and $20 \mathrm{~mm}$ thickness using standard consolidometers according to ASTM D 2435. The samples were prepared by adding $\mathrm{NaCl}$ and $\mathrm{CaCl}_{2}$ solutions with different concentrations to the basalt soil and bentonite mixtures, and the initial water content of the samples was adjusted to the liquid limit. The inside of the ring was smeared with a very thin layer of silicon grease in order to avoid friction between the ring and soil sample. Filter paper was placed at the bottom and top of the sample. A top cap with a porous stone was placed above the soil sample. The entire assembly was placed in the consolidation cell and positioned in the loading frame. The consolidation ring was immersed in the liquid with the same composition as the saturating fluid, and the entire consolidation cell was enclosed within a plastic bag to reduce evaporation. Then the consolidation cells were allowed to equilibrate for $24 \mathrm{~h}$ prior to commencing the test. All the samples were initially loaded with a stress of $4.9 \mathrm{kPa}$, increasing by an increment ratio of 1 to a maximum pressure of $1256 \mathrm{kPa}$.

\section{Determination of hydraulic conductivity}

From the consolidation test result, a time-settlement curve was obtained at each pressure increment. The coefficient of consolidation $c_{v}$ was obtained using Taylor's square root time $(\sqrt{ } \mathrm{T})$ method. The coefficient of permeability, $k$, was calculated by the 
following equation for various pressure increments using the $c_{\mathrm{v}}$, and coefficient of volume change, $m_{\mathrm{v}}$

$k=c_{\mathrm{v}} m_{\mathrm{v}} \gamma_{\mathrm{w}}$

where, $\gamma_{w}$ is the unit weight of the pore fluid

\section{RESULTS AND DISCUSSION}

\section{Liquid Limit}

The influence of the pore fluid on the liquid limit is shown in Fig. 1. With increasing salt concentration the liquid limit decreased. For a given concentration, the $\mathrm{NaCl}$ solution gave a higher liquid limit than the $\mathrm{CaCl}_{2}$ solution. These trends are quite consistent with diffuse double layer theory. Increasing the salt concentration and the cation valence decreases the inter-particle repulsion which leads the particles to become free to move at lower water contents or lower inter-particle distances, resulting in the decrease of the liquid limit (Warkentin, 1961). Figure 1 also shows that the change in the liquid limit is small for the concentration range of 0.001 to $0.01 \mathrm{~mol}_{\mathrm{c}} / \mathrm{L}$.

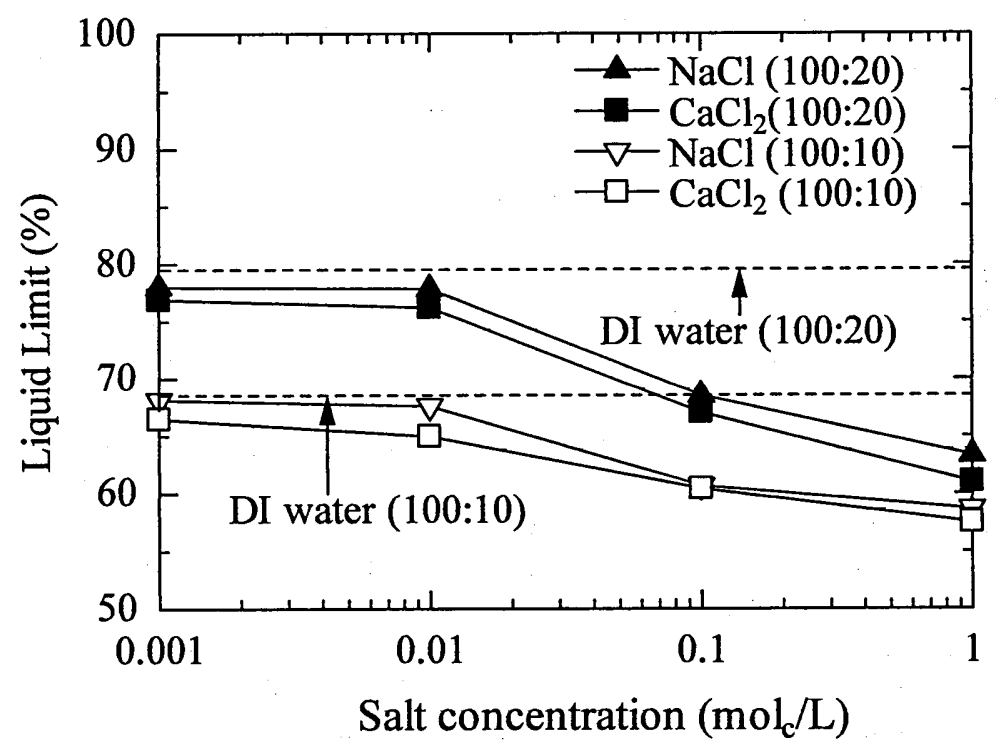

Fig. 1. Effect of salt concentration on liquid limit of soil mixtures.

\section{Free swelling}

Results of the free swelling test for different salt concentration of $\mathrm{NaCl}$ and $\mathrm{CaCl}_{2}$ solutions are shown in Fig. 2. At the same salt concentration more swelling occurred for $\mathrm{NaCl}$ than for $\mathrm{CaCl}_{2}$. For $\mathrm{NaCl}$ solutions osmotic as well as hydration swelling takes place, 
allowing the interlayer spacing to become large while for $\mathrm{CaCl}_{2}$ solutions only hydration swelling takes place (Norrish and Quirk, 1954; Zhang et al., 1995). With increasing the salt concentration, the swelling volume decreased. When the concentration of cations in the bulk solution increases, water leaves the interlayer region due to the gradient of free energy induced by the elevated concentration in the bulk pore water. A significant reduction in swelling took place when the $\mathrm{NaCl}$ concentration was increased from 0.1 to 1 $\mathrm{mol}_{\mathrm{c}} / \mathrm{L}$. At $1 \mathrm{~mol}_{\mathrm{c}} / \mathrm{L}$ the swelling volume was almost the same for the $\mathrm{NaCl}$ and $\mathrm{CaCl}_{2}$ solutions where the interlayer spacing is nearly equal to four monolayers of water (Zhang et al., 1995).

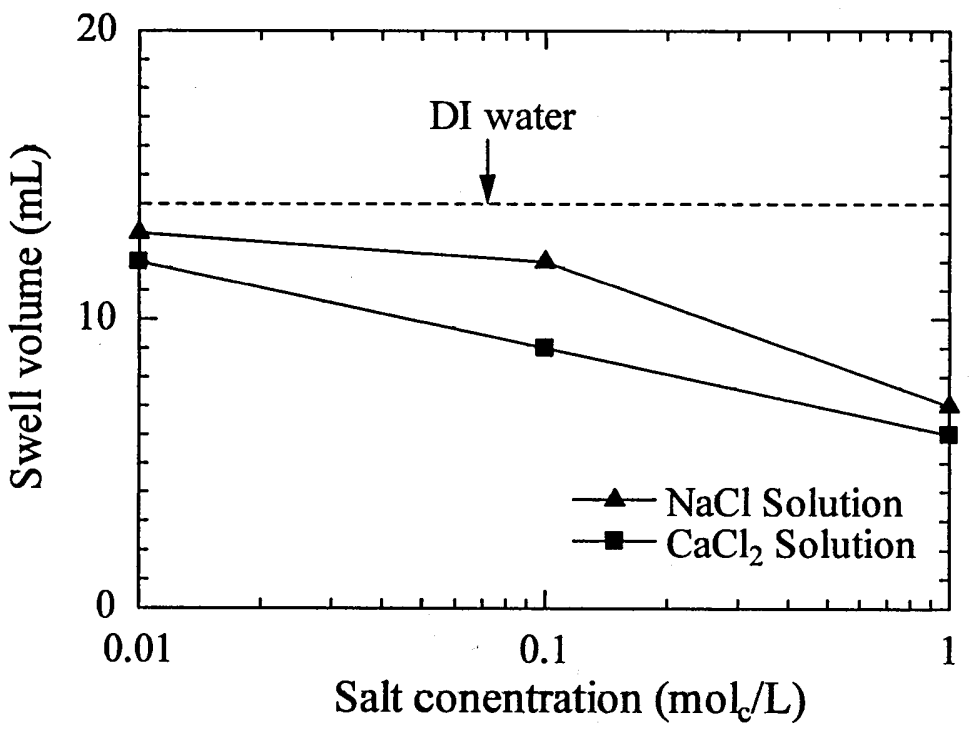

Fig. 2. Effect of salt concentration on swelling of bentonite.

\section{Hydraulic conductivity}

The hydraulic conductivity of the soil and bentonite mixtures was calculated for various pressures in the consolidation test using experimentally determined $c_{\mathrm{v}}$ and $m_{\mathrm{v}}$. Figures 3 to 6 show the relationship between the void ratio and hydraulic conductivity $(k)$ for salt solutions with different concentrations. From the figures it can be seen that $\log k$ varied almost linearly with the void ratio. Similar observations have been reported by other investigators (Olson and Daniel, 1981; Pandian et al., 1995) for the samples permeated with pure water. Each of these plots shows that the $k$ decreases with decreasing void ratio. This reduction results from the decreased void space available for flow and probably a re-orientation of the particles perpendicular to the direction of flow, thereby increasing the tortuosity factor (Quigley et al., 1966). Each of these figures also indicates that $k$ is consistently lower when the electrolyte concentration in pore water is 


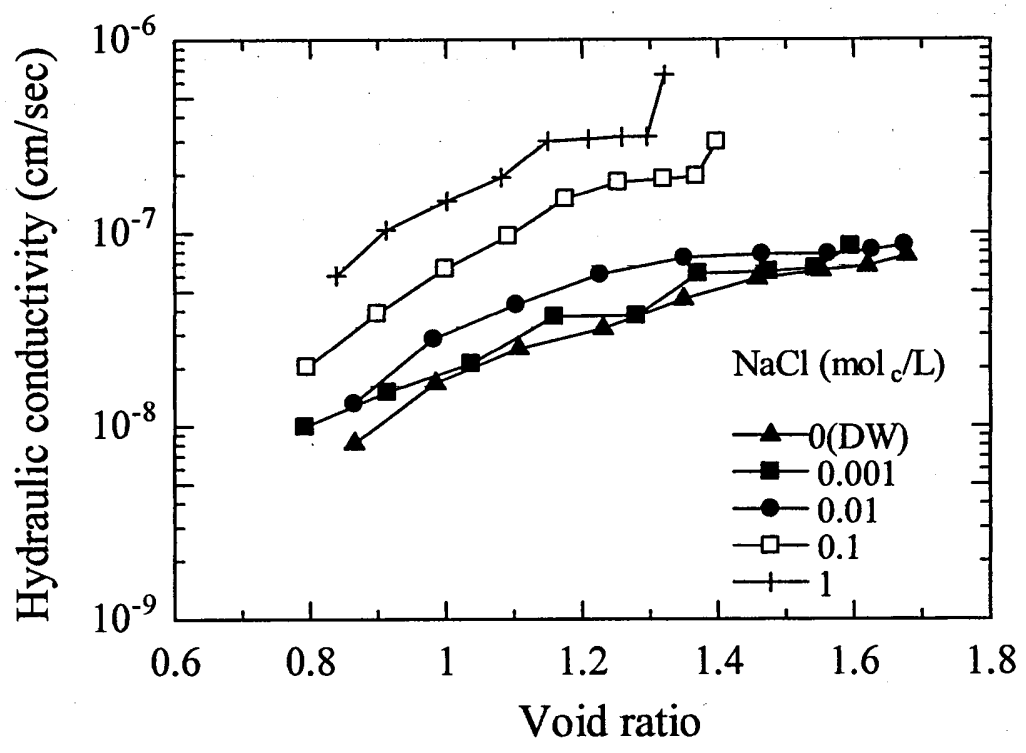

Fig. 3. Hydraulic conductivity versus void ratio for different concentration of $\mathrm{NaCl}$ solution for 100:20 mixtures.

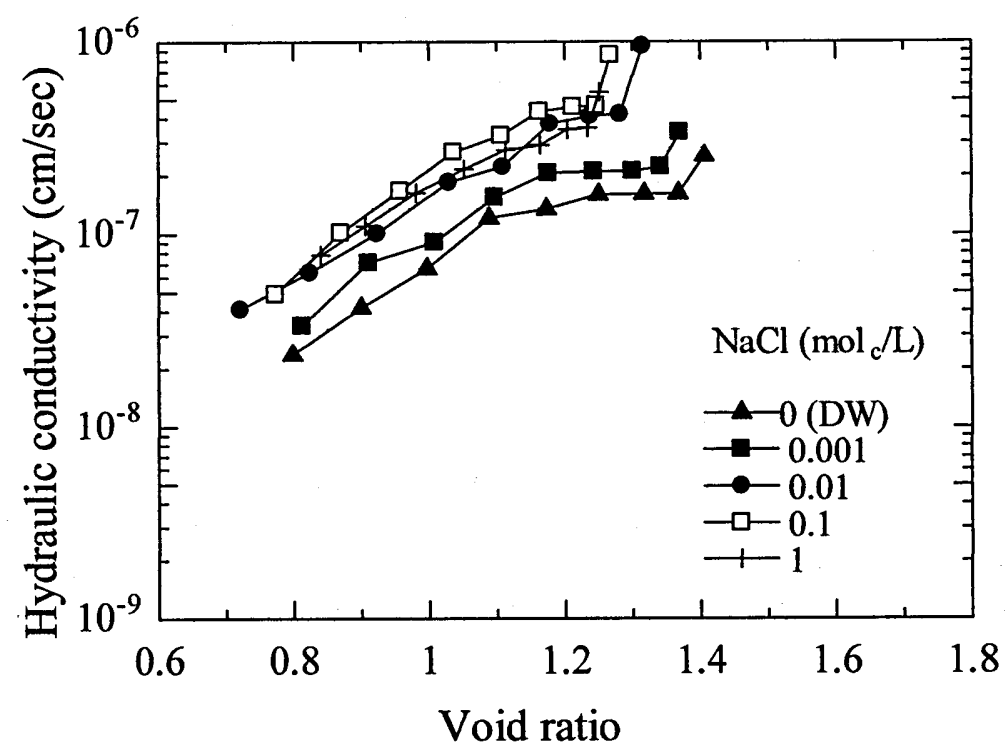

Fig. 4. Hydraulic conductivity versus void ratio for different concentration of $\mathrm{NaCl}$ solution for 100:10 mixtures. 


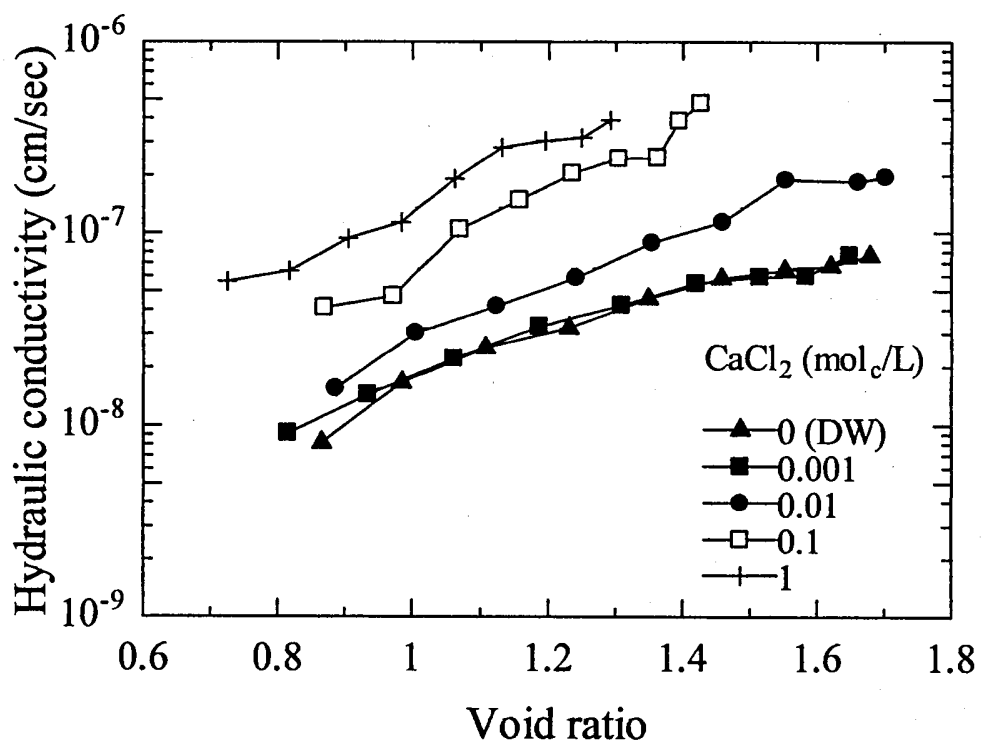

Fig. 5. Hydraulic conductivity versus void ratio for different concentration of $\mathrm{CaCl}_{2}$ solution for 100:20 mixtures.

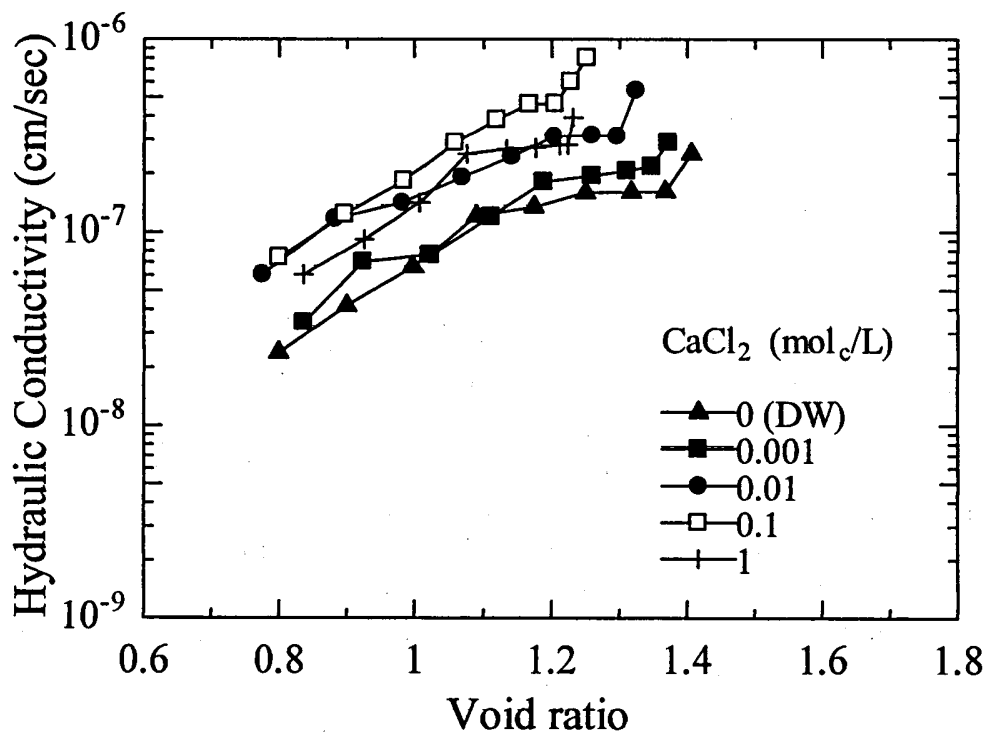

Fig. 6. Hydraulic conductivity versus void ratio for different concentration of $\mathrm{CaCl}_{2}$ solution for 100:10 mixtures. 
lower, suggesting that the water flow was retarded by the development of a diffuse double layer. The change in $k$ at a given void ratio was greater for the concentration above $0.01 \mathrm{~mol}_{\mathrm{c}} / \mathrm{L}$ than below $0.01 \mathrm{~mol}_{\mathrm{c}} / \mathrm{L}$.

The comparison between Figs. 3 and 4, and Figs. 5 and 6 show that $k$ decreased to a greater extent for lower salt concentration when the relative proportion of the basalt soil and bentonite was changed from 100:10 to 100:20. With increasing salt concentration the difference in $k$ between the 100:10 and 100:20 mixtures decreased. The ratio of $k$ for the 100:10 mixture to that of the 100:20 mixture was in a range of 3.3 to 4 for 0 to $0.01 \mathrm{~mol}_{\mathrm{c}} / \mathrm{L}$ of salt solutions. With increasing salt concentration, this ratio decreased to $2.2-1.9$ for $0.1 \mathrm{~mol}_{\mathrm{c}} / \mathrm{L}$ and $1.2-1.0$ for $1 \mathrm{~mol}_{\mathrm{c}} / \mathrm{L}$ salt solution. Figure 1 shows a similar trend for the liquid limit of the two mixtures with different $\mathrm{NaCl}$ and $\mathrm{CaCl}_{2}$ concentrations. The comparisons between the Figs. 3 and 5, and Figs. 4 and 6 show that at a given concentration the 100:10 and 100:20 mixtures with $\mathrm{CaCl}_{2}$ solution exhibit higher $k$ value than the mixture with $\mathrm{NaCl}$ solution. The higher $k$ for $\mathrm{CaCl}_{2}$ is due to the less swelling and higher flocculation of bentonite in the mixtures. These figures also show that the change in the permeability due to change in the concentration is higher for $\mathrm{NaCl}$ than for $\mathrm{CaCl}_{2}$ solutions. Similar observations were reported by Quirk and Schofield (1955) and by Mesri and Olson (1971).

Table 2. Hydraulic conductivity for salt solutions of different concentrations at the void ratio corresponding to maximum dry density

\begin{tabular}{ccccc}
\hline \multirow{2}{*}{$\begin{array}{c}\text { Salt } \\
\text { concentration } \\
\text { (molc/L) }\end{array}$} & \multicolumn{4}{c}{ Hydraulic conductivity (cm/sec) } \\
\cline { 2 - 5 } & $\mathrm{NaCl}$ & $\mathrm{CaCl}_{2}$ & $\mathrm{NaCl}$ & $\mathrm{CaCl}_{2}$ \\
\hline 0 (DI water) & $2.5 \times 10^{-8}$ & $2.5 \times 10^{-8}$ & $6.6 \times 10^{-8}$ & $6.6 \times 10^{-8}$ \\
0.001 & $3.1 \times 10^{-8}$ & $2.6 \times 10^{-8}$ & $8.8 \times 10^{-8}$ & $7.2 \times 10^{-8}$ \\
0.01 & $4.3 \times 10^{-8}$ & $4.2 \times 10^{-8}$ & $1.6 \times 10^{-7}$ & $1.4 \times 10^{-7}$ \\
0.1 & $1.3 \times 10^{-7}$ & $1.2 \times 10^{-7}$ & $1.9 \times 10^{-7}$ & $1.8 \times 10^{-7}$ \\
1 & $2.3 \times 10^{-7}$ & $2.4 \times 10^{-7}$ & $1.8 \times 10^{-7}$ & $1.6 \times 10^{-7}$ \\
\hline
\end{tabular}

The hydraulic conductivities for the mixtures permeated with water at the void ratio corresponding to the maximum dry density are tabulated in Table 2 . It is seen that $k$ increases with increasing salt concentration. For the 100:20 mixture, $k$ for $1 \mathrm{~mol}_{\mathrm{c}} / \mathrm{L}$ solution was almost 10 times as high as for the DI water. The table also shows that $k$ increased marginally when the salt concentration was raised from 0 to $0.01 \mathrm{~mol}_{\mathrm{c}} / \mathrm{L}$ but with a further increase in salt concentration $k$ increased significantly. This rapid change in $k$ with increasing salt concentration beyond $0.01 \mathrm{~mol}_{c} / \mathrm{L}$ is due to a significant decrease in interlayer swelling (Norrish and Quirk, 1954). The data for the 100:10 mixture show that $k$ was unaffected when the salt concentration increased from 0.01 to $1 \mathrm{~mol}_{c} / \mathrm{L}$.

\section{Compressibility}

The compressibility of fine grained soil depends not only on the mechanical properties of the constituent clay minerals but also on the physiochemical properties of 
the pore fluid like cation valency and salt concentration (Bolt, 1956). Figures 7 to 10 show the effects of salt concentration $\left(\mathrm{NaCl}\right.$ and $\mathrm{CaCl}_{2}$ ) on the compressibility of 100:10 and 100:20 soil--bentonite mixtures. These plots show that the compression curves are dependent on the salt concentration as well as on the type of cation, suggesting pronounced effect of the diffuse double layer on the compressibility behaviour. For less concentrated pore fluid, the compression can be seen from the initial portion of the curves and they look like a virgin compression curve for the entire range of loading. Decrease in the void ratio due to an increase in the overburden pressure was greater for the mixtures with less concentration salt. The overall compression decreased with increasing salt concentration. The mixtures with less salt concentration exhibited higher void ratios until a higher pressure was reached. These can be attributed to the reduction in diffuse double layer thickness due to an increase in the salt concentration (Olson and Mesri, 1970; Sridharan et al., 1973; Mitchell, 1976). The comparisons between Figs. 7 and 8 , and Figs. 9 and 10 show that an increase in the proportion of bentonite in the mixture led to an increase in the compressibility. The effect of salt concentration on the compressibility was of less extent for the 100:10 mixture than for the 100:20 mixture. This trend was similar to that observed for the hydraulic conductivity. Figures 7 and 9 show that the mixtures with $0,0.001$ and $0.01 \mathrm{~mol}_{\mathrm{c}} / \mathrm{L}$ give similar compression curves. With a further increase in the salt concentration, the compressibility changed significantly.

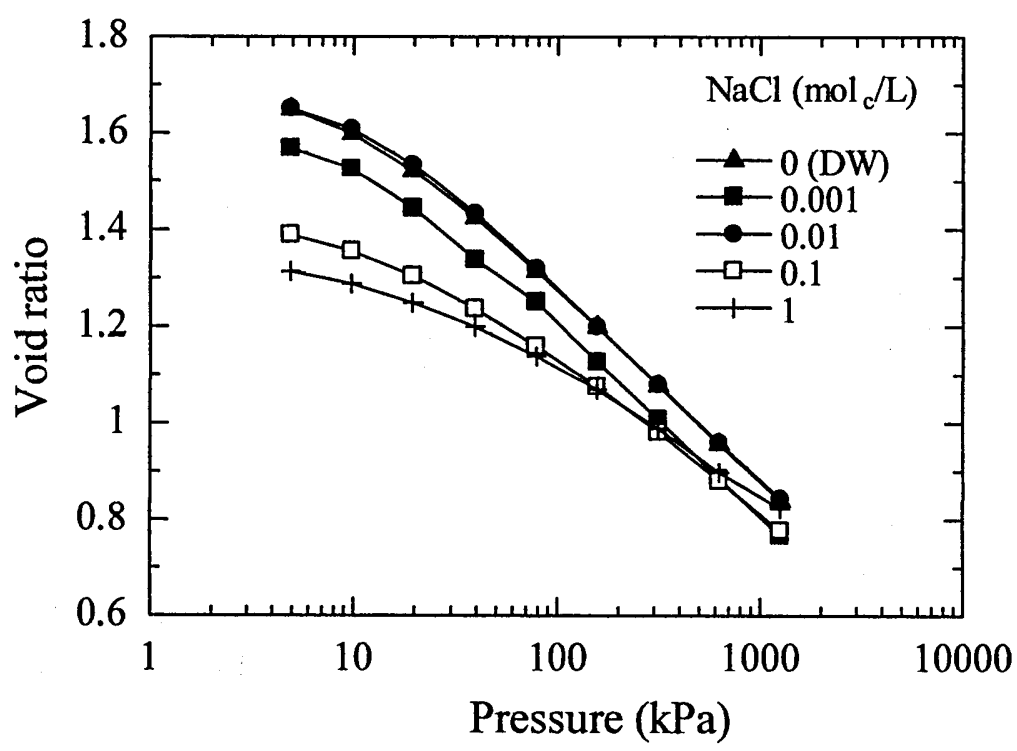

Fig. 7. Pressure versus void ratio for different concentration of $\mathrm{NaCl}$ solution for 100:20 mixtures. 


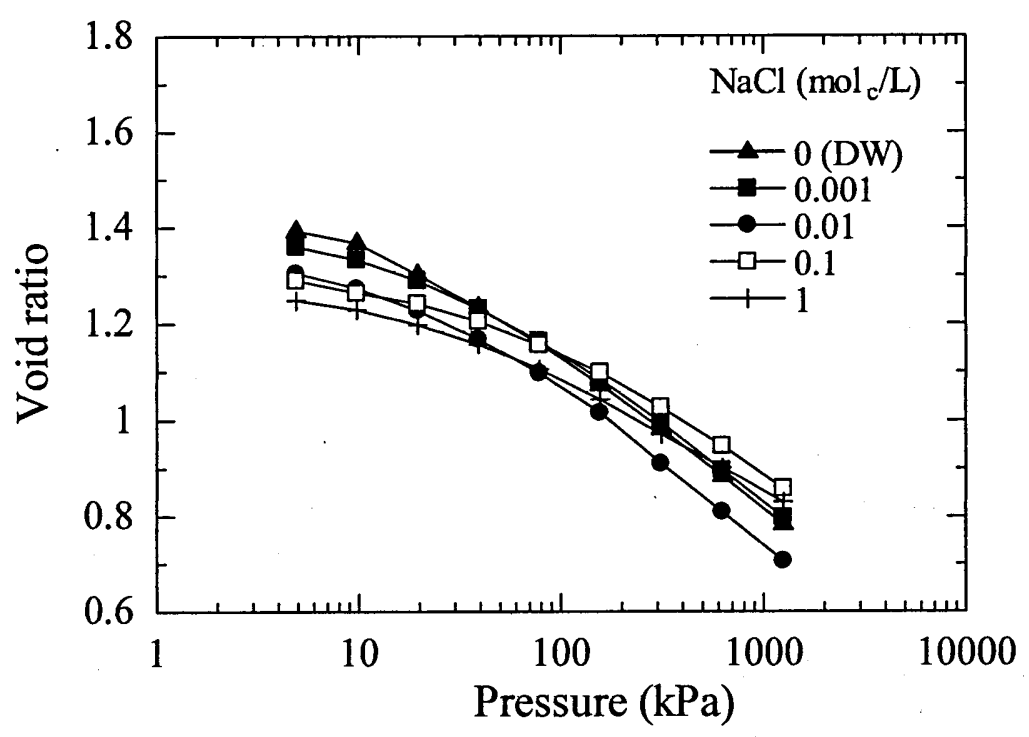

Fig. 8. Pressure versus void ratio for different concentration of $\mathrm{NaCl}$ solution for 100:10 mixtures.

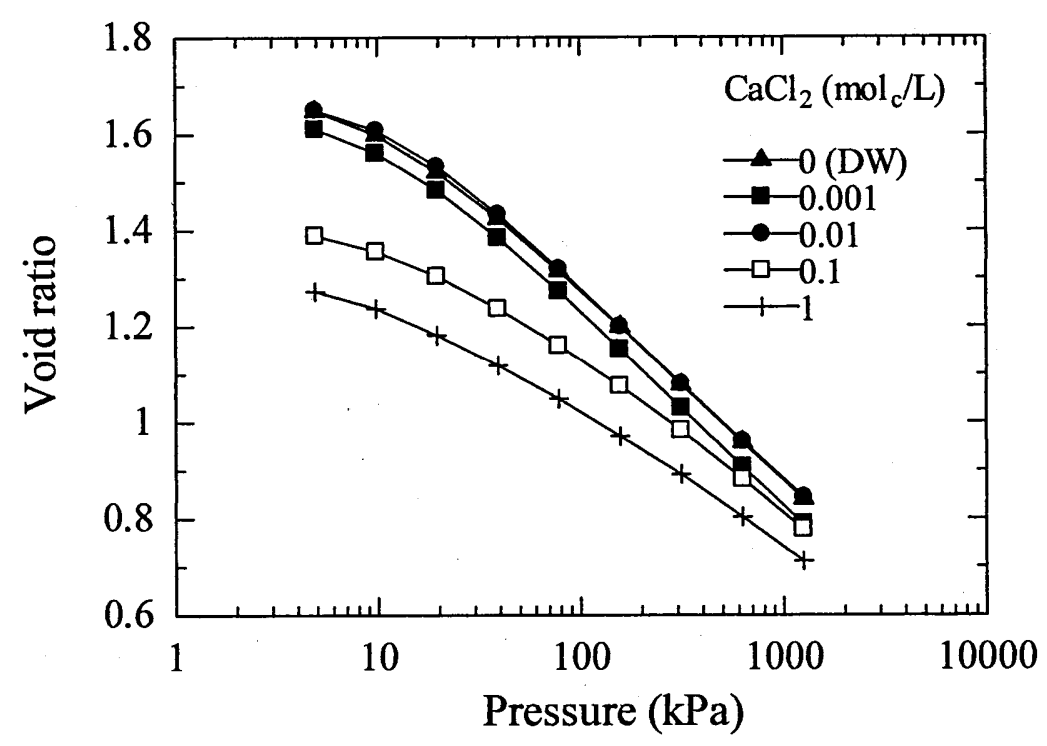

Fig. 9. Pressure versus void ratio for different concentration of $\mathrm{CaCl}_{2}$ solution for 100:20 mixtures. 


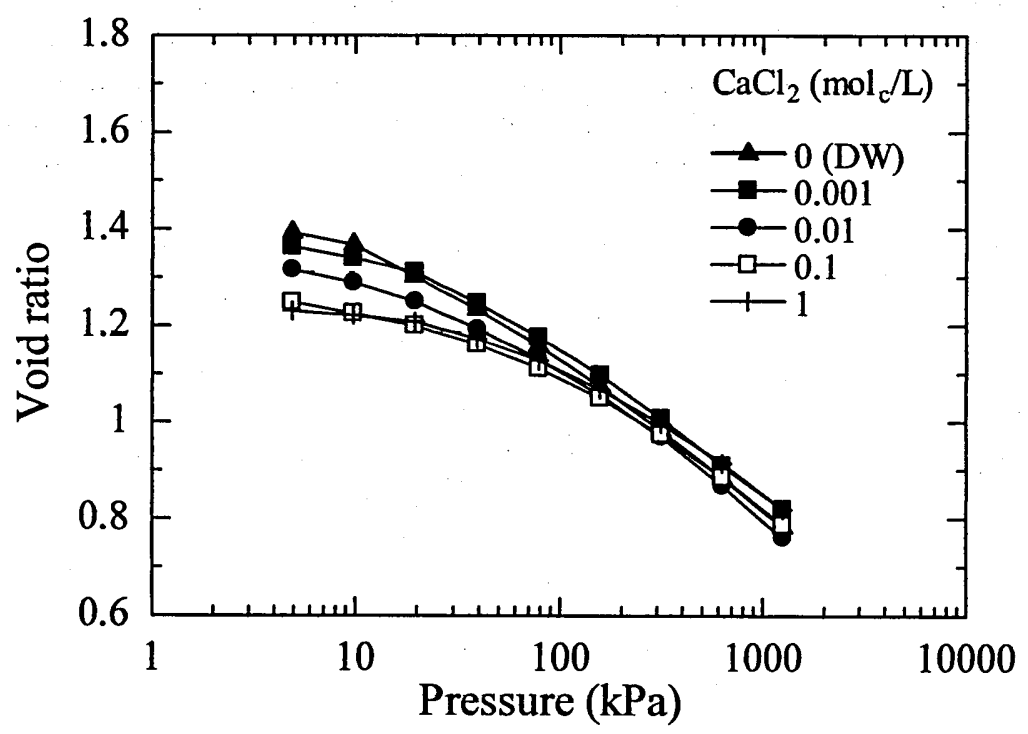

Fig. 10. Pressure versus void ratio for different concentration of $\mathrm{CaCl}_{2}$ solution for 100:10 mixtures.

Table 3. Effect of salt concentration on compression index $(C c)$

\begin{tabular}{ccccc}
\hline \multirow{2}{*}{$\begin{array}{c}\text { Salt } \\
\text { concentration } \\
\left(\mathrm{mol}_{\mathrm{c}} / \mathrm{L}\right)\end{array}$} & \multicolumn{2}{c}{$100: 20$ mixture } & $\mathrm{NaCl}$ & $100: 10$ mixture \\
\cline { 2 - 5 } & $\mathrm{NaCl}$ & $\mathrm{CaCl}_{2}$ & 0.291 & $\mathrm{CaCl}_{2}$ \\
\hline 0 (DI water) & 0.361 & 0.361 & 0.276 & 0.291 \\
0.001 & 0.355 & 0.341 & 0.257 & 0.272 \\
0.01 & 0.343 & 0.353 & 0.196 & 0.265 \\
0.1 & 0.263 & 0.237 & 0.184 & 0.201 \\
1 & 0.233 & 0.231 & 0.195 \\
\hline
\end{tabular}

Table 3 shows that with increasing salt concentration the compression index $(C \mathrm{c})$ decreased. This decrease was prominent beyond a concentration $0.01 \mathrm{~mol}_{\mathrm{c}} / \mathrm{L}$, indicating a significant reduction in the thickness of the diffuse double layer beyond a concentration of $0.01 \mathrm{~mol}_{\mathrm{c}} / \mathrm{L}$ (Mathew and Rao, 1997). The table also shows that increasing in the proportion of bentonite in the mixture caused an increase in $C \mathrm{c}$.

\section{SUMMARY AND CONCLUSION}

The consolidation tests were performed on the mixtures of basalt soil and bentonite in the proportion of 100:10 and 100:20 to evaluate the effect of salt on the permeability 
and compressibility of the soil mixtures. The test results demonstrated that the salt concentration has pronounced effects on the permeability and compression of the soil mixtures, and the extent of change in the hydraulic conductivity and compression parameters was different according to the salt concentration range. The salt concentration effects were found to be more pronounced for the composition with higher bentonite percentage.

When the salt concentration was increased from 0 to $0.01 \mathrm{~mol}_{\mathrm{c}} / \mathrm{L}$, there was a marginal change in both hydraulic conductivity and compressibility, but increased significantly with further increase in salt concentration for both $\mathrm{NaCl}$ and $\mathrm{CaCl}_{2}$. The hydraulic conductivity at a given void ratio exhibited slight increase in a range of 0 to $0.01 \mathrm{~mol}_{c} / \mathrm{L}$ but significant increase in a higher salt concentration range.

The compression index decreased with increasing salt concentration, and the change was small in a range of 0 to $0.01 \mathrm{~mol}_{\mathrm{c}} / \mathrm{L}$ while it was significant for further increase of salt concentration. The trend for the change in the compression index by salt concentration agreed with that for the liquid limit, where the liquid limit of the complexes decreased with increasing salt concentration of both $\mathrm{NaCl}$ and $\mathrm{CaCl}_{2}$.

\section{REFERENCES}

Bolt, G. H. 1956 Physico-chemical analysis of the compressibility of pure clays. Geotechnique, $\mathbf{6 ( 1 )}$ 86-93

Budhu, M. 1991 The permeability of the soils with organic fluids. Canadian Geotechnical Joumal 28: 140-147

Casagrande, A. and Fadum, R. E. 1944 Notes on soil testing for engineering purposes: Soil Mech. Series No. 8 Harvard Graduate School of Engineering.

Daniel, D. 1994 State-of-the-art: Laboratory hydraulic conductivity tests for saturated soils. Hydraulic conductivity and waste contaminant transport in the soil, STP 1142, D. Daniel and S. Trautwein, eds., ASTM, West Conshohocken, Pa., 30-78

Gleason, M., Daniel, D. E. and Eykholt, G. R. 1997 Calcium and sodium bentonite for hydraulic containment applications. Journal of Geotechnical and Geoenvironmental Engineering ASCE, 123(5): $438-445$

Ho Young Jo, Takeshi Katsumi, Craig H. Benson and Tuncer B. Edil 2001 Hydraulic conductivity and swelling of nonprehydrated GCLs permeated with single-species salt solutions. Journal of Geotechnical and Geoenvironmental Engineering ASCE, 127(7): 557-567

Madsen, F. T. 1994 Clays and synthetic liners-durability against pollutant attack. In Proceedings of the $13^{\text {th }}$ International Conference on Soil Mechanics and Foundation Engineering, New Delhi, 5: 287-288

Mathew, K. and Narasimha Rao, N. 1997 Influence of cations on compressibility behavior of a marine clay. Journal of Geotechnical and Geoenvironmental Engineering ASCE, 123(11): 1071-1073

Mesri, G., and Olsen, R. E 1971 Mechanisms controlling the permeability of clays. Clay and Clay Minerals, 19: 151-158

Mesri, G., and Olsen, R. E 1971 Consolidation characteristics of montmorillonite. Geotechnique 21(4): 341-352

Mitchell, J. K. and Madson, F. T., 1987 Chemical effects on the clay hydraulic conductivity. In Geotechnical practice for waste disposal. American Society for Civil Engineers, New York, 87-116

Mitchell, J. K. 1976 Fundamentals of Soil Behavior. John \& Wiley \& Sons, Inc., New York

Newland, P. L., and Alley, B. H. 1960 A study of consolidation characteristics of a clay. Geotechnique, 10: $62-74$

Norrish, K. and Quirk, J. 1954 Crystalline swelling of montmorillonite; use of electrolyte to control swelling. Nature, 173: 255-257

Ohtsubo, M. Loretta, Y. Li, Yamaoka, S, Higashi, T 2004 Leachibility of heavy metals and salt from bottom ash. Proc. $5^{\prime \prime}$ Geoenvironmental Engineering Symposium, Japanese Geotechnical Society, 
$169-174$

Olson, R. E., and Daniel, D. E. 1981 Measurement of hydraulic conductivity of fine grained soils. In Permeability and ground water contaminant transport. American Society for Testing and Materials, Special Technical Publication STP 746, 18-60

Olson, R. E., and Mesri, G. 1970 Mechanism controlling compressibility of clays. ASCE, Journal of Soil Mechanics and Foundation Division, 96(6): 1863-1878

Pandian, N. S., Nagaraj, T. S., and Narasimha Raju, P. S. R. 1995 Permeability and compressibility behaviour of bentonite-sand/soil mixes. Geotechnical Testing Journal, 18(1): 86-93

Petrov, R. J., and Rowe, R. K. 1997 Geosynthetic clay liner (GCL) chemical compatibility by hydraulic conductivity testing and factors impacting its performance. Canadian Geotechnical Journal, 34: $863-885$

Quigley, R. M and Thompson, C. D. 1966 The fabric of anisotropically consolidated sensitive marine clay. Canadian Geotechnical Journal, 3(2): 61-73

Quirk, J. P., and Schofield, R. K. 1955 The effect of electrolyte concentration on soil permeability. Jourmal of Soil Science, 6(2): 163-178

Ruhl, J. L., Daniel D. E. 1997 Geosynthetic clay liners permeated with chemical solutions and leachate. Journal of Geotechnical and Geoenvironmental Engineering ASCE, 123(4): 369-381

Sivapullaiah, P. V., Sridharan, A. and Stalin, V. K. 2000 Hydraulic conductivity of bentonite-sand mixtures. Canadian Geotechnical Journal, 37: 406-413

Sridharan, A. and Rao, G. V. 1973 Mechanism controlling volume change of saturated clay and the role of effective stress concept. Geotechnique 23(3): 359-382

Studds, P. G, Stewart, D. I and Cousen, T. W. 1998 The effect of salt solutions on the properties of bentonite-sand mixtures. Clay Minerals 33: 651-660

Taylor, D. W 1942 Research on consolidation of clays, Serial 82, Massachusetts Institute of Technology, Department of Civil Engineering, Cambridge

Terzaghi, K. T. 1923 Die Berechnung der Durchlassigkeitsziffer des Tons aus dem Verlauf der hydrodyanamischen Spannungserscheinungen, Akademia der Wissenschaften in Wien. Sitzungsberichte, Mathematischnaturwissenschaftliche Klasse-IIa, 132: 125-138

Van Olphen, H 1963 An Introduction to Clay Colloid Chemistry. $2^{\text {nd }}$ edition, Interscience publishers, New York

Warkentin, B. P. 1961 Interpretation of the upper plastic limit of clays. Nature, 190: 287-288

Yong, R. N., Sheremata, T. W. 1991 Effect of chloride ions on adsorption of cadmium from a landfill leachate. Canadian Geotechnical Journal, 28: 378-387

Zhang, F., Low, P. and Roth, C. 1995 Effects of monovalent exchangeable cations and electrolytes on the relation between swelling pressure and interlayer distance in montmorillonite. Journal of Colloid Interface Science, 173: 34-41 